УДК 821.111-2.091(74)(=161.2)

DOI 10.35433/philology.1(89).2019.48-55

Д. І. Дроздовський,

кандидат філологічних наук, науковий співробітник

(Інститут літератури ім. Т. Г. Шевченка НАН України, м. Київ)

drozdovskyi@ukr.net

ORCID: 0000-0002-2838-6086

\title{
ПСИХОЛОГІЧНА ІДЕНТИЧНІСТЬ ПЕРСОНАЖІВ БРИТАНСЬКИХ ПОСТПОСТМОДЕРНІСТСЬКИХ РОМАНІВ: ДИСКУРС ЕГО-ЛІТЕРАТУРИ
}

У статті досліджено психологізм британських постпостмодерністських романів. На матеріалі сучасних британських романів С. Вотерс, І. Мак'юена, М.Дж. Гайленд, М. Геддона, Д. Мітчелла розвинуто концепцію постмодерністських ідентичностей, представлену в роботах Ф. Штейнбука. Наголошено на перспективності представленої теорії в літературному дискурсі постпостмодернізму.

Обгрунтовано моделі репрезентації рольової ідентичності як компонента постпостмодерністської художньої ідентичності та проаналізовано конфлікти між індивідуальною ідентичністю та ідентичністю групи. Інтенсифіковане виявлення психологізму в сучасних романах детерміновано розвитком ето-літератури, яка передбачає конструювання досвідів суб 'єкта нарачї, який шляхом написання щзоденника здійснює самопізнання й водночас пояснює себе іншим. Схарактеризовано

можливості розширення теоретико-методологічного поля сучасних літературознавчих досліджень иляхом залучення психологічних підходів і результатів досліджень особистісної ідентичності в аспекті теорії ігор, трансактного аналізу тощчо.

Ключові слова: постпостмодернізм, британський роман, его-роман, рольові ідентичності, аутизм, постпостмодерністські ідентичності, література факту.

Постановка проблеми. Для постпостмодерністського роману визначальним є мотив перебування персонажів у множинній реальності, що, відповідно, накладає відбиток і на саму ідентичність персонажів. Переживши значне психоемоційне потрясіння чи травму в минулому ("Маленький незнайомець" С. Вотерс, "Спокута" І. Мак’юена, "Угамуйте мене" М. Дж. Гайленд та ін.), персонажі постпостмодерністського роману конструюють фіктивну ідентичність, що виникає як форма захисту від пережитого болю. Сформовані фіктивні ідентичності реалізуються відповідно до законів, пов'язаних із захисною діяльністю психіки. Отже, окреслений спектр ідентичностей репрезентований не лише в постмодерністській літературі, як зауважує Ф. Штейнбук, а й також представлений у сучасному британському романі. Л. Чорна, досліджуючи різні вияви ідентичності й зокрема місце локалізації рольової ідентичності серед інших видів ідентичності особистості, зазначає, що прийнятому сьогодні визначенню ідентичності бракує психологічного компонента, "бо ролі $є$ не тільки соціальними, конвенціональними, аскриптивними, формальними, а й міжособовими, психологічними, життєвими, неформальними. У кожної ролі є об’єктивний і суб'єктивний змісти. Інтеріоризація об'єктивних змістів ролей i наповнення їх суб’єктивними становлять процес формування рольової ідентичності особистості" [1: 122].

Аналіз останніх досліджень і публікацій. Результати досліджень психології особистості в аспекті репрезентації рольових ідентичностей $[1 ; 2 ; 3 ; 4 ; 5 ; 6]$ активно залучені до поля методологічних шукань i орієнтирів у річищі новітніх теоретико-літературознавчих досліджень. Психологічні методи вивчення літератури дають можливість глибше пізнати особливості психологізму, розкрити ідентичнісну специфіку персонажів сучасних (постмодерністських, постпостмодерністських) художніх творів. Так, Фелікс Штейнбук, досліджуючи постмодерністську літературу, здійснює класифікацію основних художній ідентичностей, репрезентованих в аналізованих художніх творах. Послуговуючись методом тілесного міметизму, який розробив сам дослідник, а також "топологічною рефлексією" [7: 106], літературознавець пропонує таку типологію ідентичностей, представлених в антропологічній проекції: "Патологія ідентичності; іронія ідентичності; фальшива ідентичність; експліцитна ідентичність; автентика ідентичності; ідентичність монстра; множинна ідентичність; ідентичність парапраксії; кафкіанська ідентичність; "фігур[и] неспроможності" (В. Беньямін)" [7]. Зазначена класифікація водночас потверджує правильність власних теоретичних шукань у площині англійського постпостмодерністського роману, у якому натрапляємо на подібні вияви художній ідентичнісних репрезентацій, щоправда, деякі 3 них потребують уточнень. Найперше дозволю наголосити на тому, що представлена типологічна класифікація антропологічних художніх ідентичнісних типів детермінована залученням психологічних досліджень до літературознавства.

Дослідження різних аспектів ідентичності має особливу значущість у річищі сучасної гуманітаристики. Концепція дифузної, відстроченої, досягнутої, психосоціальної ідентичності репрезентована в роботах Е. Еріксона $[8 ; 9 ; 10]$. Вивчення ідентичності та їі літературних репрезентацій у 
сучасних британських романах оприявнює ще одну теоретичну проблему: особливості кореляції між художнім світом сконструйованих персонажів і жанровими різновидами постпостмодерністського роману. Дослідники сучасної культури й зокрема літератури наголошують на актуалізації в ній психологізму, який уможливлює посилене виявлення емоційних реакцій персонажів, розкриваючи специфіку їх психоемоційної взаємодії із зовнішнім світом тощо.

У сучасній теорії літератури дедалі виразнішим $є$ уживання поняття "его-роман" $[11 ; 12 ; 13]$ для ідентифікації романів, написаних у річищі "літератури факту" й саме від першої особи. "Его-роман" актуалізує посилену увагу до суб'єкта нарації, особливостей когнітивних процесів, що позначаються на світосприйнятті дійсності. Крім того, стратегії "его-роману" детермінують ефект "глибокого занурення" реципієнта у процесі читання, даючи можливість зблизитися з мисленнєвими процесами персонажів, увійти у простір внутрішніх переживань, рефлексій тощо. "Его-роман" репрезентує напрям літератури, у якому важливо показати простір літератури як фактологічно достовірний феномен, який може містити важливі інспірації або ж рефлексії, що допоможуть активізувати критичне осмислення навколишнього світу й загострено поставитися до певних соціальних, політичних, науково-технологічних процесів i явищ. Н. Колошук справедливо наголошує на тому, що "доцільно розглядати документалістику, а саме его-тексти (щоденники, мемуари, листи, автобіографічні нариси, сповіді, залишені для потомків в автентичному вигляді, без белетризації), крізь призму антропологічної, герменевтичної, феноменологічної, рецептивної методологій тощо" [11:221].

Дослідники ідентичності, як психологічного явища, наголошують на тому, що вивчення специфіки рольових ідентичностей допоможе у розв'язанні низки наукових проблем, які, на нашу думку, стосуються не лише царини психології, а й літературознавства, зокрема теорії постпостмодерністської ідентичності: "наповнення поняття рольової ідентичності психологічними змістами; - інтеграція різних ролей особистості в єдину рольову ідентичність; - становлення людини як суб'єкта ролей, реалізація творчого потенціалу особистості; - свідомі і несвідомі, позитивні і негативні компоненти процесу формування рольової ідентичності особистості; - побудова єдиної теорії ідентичностей особистості, яка охоплювала б і рольову" [1: 124]. Зазначені наукові проблеми стосуються й простору літератури. "Інтеграція різних ролей особистості", становлення персонажа "як суб'єкта ролей", "побудова єдиної теорії ідентичностей" художніх персонажів належить до пріоритетних завдань сучасної теорії літератури. Персонажі постпостмодерністських романів приміряють на себе кілька ідентичностей (накинутих суспільством зовні, а також ті, що формуються всередині персонажів відповідно до усвідомлення власної моделі поведінки, сформованих цінностей, життєсвіту тощо). "Завдяки розвиткові процесів мислення, усвідомлення, рефлексії, комунікативних здібностей, а також застосуванню в індивідуальних випадках психотерапевтичних практик, насамперед трансактного аналізу та психодрами, первинні рольові ідентифікації узагальнюються, переструктуровуються, оцінюються людиною (читай: персонажем художнього твору. - Д.Д.) - формується індивідуальна рольова ідентифікація" [1: 125]. Подібна тенденція особливо вияскравлена в постпостмодерністських романах, які доцільно зарахувати до категорії "літератури факту" або ж категорії "его-романів".

Формулювання мети і завдань статті. Окреслити реактуалізацію психологічних компонентів у дискурсі британського постпостмодерністського роману, схарактеризувавши причини посиленої репрезентації психологічних аспектів у конструюванні персонажів. Завдання роботи полягає у з'ясуванні психологічної природи рольових ідентичностей персонажів британського постпостмодерністського роману; окресленні концепції постпостмодерністської ідентичності, представленої в сучасних романах Великої Британії (2000-2010-х рр.).

Виклад основного матеріалу. Для Кристофера 3 "Дивного випадку..." М. Геддона автентикою власних ідентичнісних пошуків стає феномен простих чисел. Потрактування математики як ідеальної мови для пізнання світоустрою й формування власних зв'язків із дійсністю позначається на тому, що протагоніст сприймає себе як просте число, тобто стає феноменом, що дорівнює тільки собі. Просте число ділиться на себе й на одиницю. Кристофер як носій аутичного мислення не може ставити себе на місце інших, не може "проживати" інші досвіди: персонаж роману Марка Геддона дошукується власної сутності, водночас у романі подано спробу розкрити феноменологію аутичного мислення, показавши автентичні та іманентні принципи мислення такого персонажа, розкривши сутність його раціональних та емоційних виявів стосовно явищ зовнішнього світу. В. Дуркалевич звертає увагу на те, що "спогади про особисті події <..> чи я-окреслюючі спогади <..> нав'язують до важливих емоційно насичених епізодів, у які глибоко заангажоване "я". Окремі епізоди мають вигляд складних невирішених питань, супроводжуються негативними афективними переживаннями i вимагають інтенсифікації зусиль, спрямованих на їхнє розв'язання. Проектування цих переживань у сферу я-наративів сприяє глибшому їх розумінню й освоєнню-опануванню, інтеграції у цілісну автобіографічну історію. Цілісність $\epsilon$, отже, результатом перманентного синтезу часово різних досвідів-переживань <..>. Від цього синтезу залежить стабільність ідентичності" [14: 15-16]. Стабільність ідентичності аутичного персонажа в романі М. Геддона доводить його статус як Іншого, а не Чужого. Здатність юнака створювати я-наратив у формі 
щоденника засвідчує готовність пропрацювати пережиті травматичні досвіди задля їх глибшого розуміння, відповідно до міркувань В. Дуркалевич. Фактично щоденник допомагає реципієнтові роману візуалізувати цілісну автобіографічну історію Кристофера. Детективна лінія, що постає пусковим механізмом, із часом відходить на другий план у "Дивному випадку...", а на першому експліковано автобіографічну історію, яка свідчить про готовність суб'єкта нарації до пропрацювання складних питань, із якими доводиться мати справу в реальному житті.

У романі "Хмарний атлас" Д. Мітчелла так само наявна спроба репрезентувати вияви автентичної ідентичності, причому ідентичнісні пошуки виведено на антропологічно-цивілізаційний рівень. Оповідач прагне зрозуміти спільне в поведінці персонажів, що належать різним наративам i, відповідно, різним культурно-історичним епохам, у яких центральною силою є воля до влади, що утривалює капіталістичні відносини в суспільстві й розкриває експансивну сутність людини в аспекті потреби влади. Капіталізм постає моделлю пролонгації, по суті, рабовласництва в різні культурно-історичні періоди, що передбачає домінування сильнішої групи над слабшою, в результаті чого виникає соціальна напруженість, конфліктність, а технологічний розвиток спрямований лише на підсилення позицій однієї групи супроти іншої. Інтелектуально-технологічний вимір не корелює в романі з виміром морально-духовним, а тому приречений на катастрофічний фінал, який, щоправда, не стає кінцем історії. Якщо в постмодернізмі мотив кінця історії є особливо виразним, то в постпостмодерністському британському романі показано, що навіть після найбільшої катастрофи фатум, космічний порядок, вищі сили тощо уможливлюють існування часу й простору з самого початку. Воля до влади в "Хмарному атласі" представлена в гіпертрофованому вигляді, а тому п'ятий наратив, у якому представлено трагічний апофеоз, властивий містерії, за Б. Шалагіновим [15], репрезентує модель цивілізаційного кінця, який переживають мешканці Нео-Сеулу. Незбалансованість між розумом і мораллю завершується катастрофою, технологічним апокаліпсисом, проте шостий наратив, у якому показано можливість початку після кінця, постає художньою візуалізацією ідентичності, яку доцільно схарактеризувати як автентичну. Автентичною сутністю людини в романі є пошук метафізичного за умови екстеріоризації раціональних інтенцій; поєднання в людині первісних страхів (які, зрештою, й дають можливість вийти на рівень метафізичного розуміння дійсності) із постійним прагненням до самовдосконалення шляхом розвитку в собі пізнавальних здібностей. Проте когнітивний апарат персонажів лише почасти детермінований біологією: впливи біології можуть бути "зняті" метафізичним відчуттям світу, яке дає можливість композиторові в третьому наративі піднятися над філістерською дійсністю обивателів. Д. Мітчелл порушує соціальне питання про конфлікт індивіда й спільноти, яка не може володіти метафізичним відчуттям, позаяк воно дається лише індивідуальностям. Проте більшість персонажів роману не прагне виховувати в собі індивідуальної системи цінностей і йти шляхом самопізнання. Персонажів задовольняє копіювання форм пізнання реальності, яке поділяє більшість, вони уникають особистісної відповідальності, що й призводить до інтенсифікації обивательства в 2000-і роки й бунту роботів у далекому майбутньому.

Ідентичність Доктора Фарадея з роману "Дивний незнайомець" так само доцільно схарактеризувати як "ідентичність монстра", послуговуючись поняттям Ф. Штейнбука. "Монструозність" притаманна персонажам роману "Хмарний атлас", які в різний спосіб докладаються до підтримки імітат-реальності й прагнуть остаточно витіснити справжнє відчуття світу, замінивши його симуляцією насолод i гіпертрофованим ентертейнтментом. Пошуки справжнього, що часом містить насправді вихід у метафізичну дійсність, є одним із ключових мотивів британського постпостмодерністського роману. Іншим знаковим і в постпостмодернізмі типом ідентичності є "множинна ідентичність", яка свідчить про внутрішню багатовимірність постпостмодерністських персонажів. "Множинність" притаманна навіть персонажам із аутичним мисленням, оскільки Кристофер у "Дивному випадку..." містить внутрішню трансгресію, тобто вихід із однієї ідентичності в іншу, що, правда, є результатом порушення внутрішніх правил поведінки, які стримують персонажа в рамках "нормальної" ідентичності й дають можливість здійснювати адекватну, наскільки це можливо, взаємодію із зовнішнім світом.

Марк Геддон у "Дивному випадку із собакою вночі" розкриває, як аутичне мислення репрезентоване в сучасній англійській граматиці. Письменник створює речення, які, як зауважує С. Лофтіс [16], наближається до реального письма аутистів. Синтаксична специфіка речень художнього твору, який імітує антихудожній наратив, має сприяти "глибокому зануренню" реципієнтів у внутрішній світ протагоніста. Малюнки, схеми, графіки, скорочення, представленні у щоденнику, як і проблеми, над якими розмірковує головний персонаж, перетворюють "дивний випадок" на приклад "літератури факту" й "его-роман", у якому важливу ролі відіграє сам спосіб оповіді, який репрезентує аутичну ідентичність персонажа. Н. Колошук, аналізуючи дискурс "літератури факту" й приклади "его-літератури", наголошуючи на ширшій методологічній перспективі вивчення цього феномену літературної документалістики, зокрема в антропологічній та поетологічній перспективі: "Тексти его-документів при всій їхній тематичній та жанровій і поетикально-художній неоднорідності / нерівноцінності потребують особливої методики аналізу кожного конкретного свідчення. Вона повинна враховувати не лише критерії достовірності матеріалу та яскравість вираженої авторської суб'єктивності, а й цілу систему ідейно- 
поетикальних характеристик, передусім: масштаб узагальнення окремого людського досвіду; мистецтво відбору вражень, документів і фактів; точність і неповторність деталей, обставин, характеристик, представлених через суб'єктивну авторську оцінку; спосіб включення у текст реальних документів; вміння передати особистий досвід через конфлікт прозріння / загартування / воскресіння душі у стражданнях; безстрашність свідчень усупереч тенденціям суспільного замовчування "білих плям" історії; авторська здатність подолати зжиті ідеологічні стереотипи; жанрова і стилістична свобода та вправність оповіді; вихід поза естетичні канони своєї доби у формуванні неповторної структури документального свідчення; здатність викликати ефект катарсису" [11:221]. Роман Марка Геддона позначений "скупістю" поетологічних прийомів, що детерміновано прагненням автора наблизити художній наратив до специфіки аутичного мовлення. Подібна наративно-поетологічна стратегія сприяє формуванню читацької довіри до тексту, належного до дискурсу "его-літератури", визначальним для якої $\epsilon$ фактологічна домінанта. Водночас С. Лофтіс наголошує на стратегіях ідеалізації персонажів у романах, де головним героєм є носій аутичного мислення.

Аутична свідомість постає об'єктом маніпуляцій або ж стереотипованого сприйняття, що пов'язано 3 досі недостатнім вивченням цього явища у психології. Юнак-аутист, з одного боку, сприймається суспільством як "Інший", з другого, він "Чужий", який може становити небезпеку через те, що особливе мислення робить його потенційно носієм соціопатичної поведінки, яка виникає в результаті генетичної специфіки. Соціопати розглядаються в психологічних дослідженнях часто як представники небезпечних для суспільства моделей поведінки, яка не вписується в усталені норми, правила, а тому може бути джерелом потенційної загрози. Натомість М. Геддон, послуговуючись стратегіями "его-роману", прагне переконати читачів у тому, що Кристофер такий самий інший, як і всі реципієнти, які самі $\epsilon$ імпліцитними носіями постійних соціальних небезпек і комунікативних девіацій. Ці небезпеки, на думку М. Геддона, детерміновані особливістю соціальних ідентичностей, сконструйованих у суспільстві чи в певних суспільних групах.

Небезпека полягає в тому, що важливим елементом таких ідентичнісних масок є уміння казати неправду, здатність обманювати й створювати уявні ситуації, у яких люди взаємодіють між собою на поверховому рівні, не вдаючись до заглиблення у світ інших, а отже, не пізнаючи інших. Натомість Кристофер у романі М. Геддона потребує пояснення усіх навколишніх загадок саме на глибинному рівні, йому важливо розгадати таємницю убивства пуделя, оскільки інакше зовнішній світ поставатиме для нього джерелом непорозумінь, які неможливо пояснити раціонально. Аутичне мислення Кристофера спрямоване на виявлення закономірностей і базових законів, що визначають перебування людей у соціумі. "Его-роман" М. Геддона покликаний стерти різницю між поведінкою "здорової" людини й поведінкою аутиста із синдромом Аспергера: письменник показує, що в поведінці обох типів персонажів наявні свої правила й потреба дотримуватися певних конвенцій. Для Кристофера ідентичність "простого числа" детермінована концепцією тотальної правди, неможливістю продукувати брехню, яка б шкодила й іншим, і самому персонажеві. Цілісність (недифузність) ідентичності протагоніста "Дивного випадку..." пов'язана саме з системою внутрішніх конвенцій, дотримання яких і забезпечує реалізацію саме такого ідентичнісного типу в постпостмодерністському художньому творі. Сформований у британському суспільстві тип групової ідентичності піддається критиці в романі М. Геддона, оскільки закріплені первинні рольові неусвідомлені механізми позначаються на формуванні суспільства, у якому значну роль відведено дотриманню фейкових ролей. "Соціальна ідентичність у такому разі виступає узагальнювальним поняттям, яке містить індивідуальний і груповий іiі види. Групова ідентичність так само поділяється на ідентичності, сформовані на рівні макро- і мікрогруп. Тут можемо говорити про рольову міжособистісну і рольову соціальну ідентичності. Індивідуальна та групова ідентичності індивіда інтегруються в особистісну" [1: 127]. Під фейковими ролями розуміємо такі соціальні позиції й взаємодії між персонажами, що побудовані на дотриманні конвенцій і норм, що не мають внутрішнього усвідомлення, вони не розкривають внутрішнього світу кожної особистості, а лише дають можливість виявити ті риси ідентичності, що забезпечують удавану неконфліктність перебування в комунікативносоціальних ситуаціях. Суспільство в романі представлено різними групами (батьки, сусіди, представники поліції, учителі тощо), усередині яких важливо дотримуватися певних правил, що детермінують функціонування рольових ідентичностей.

В "Угамуйте мене" ірландсько-британської письменниці маємо приклад наративу, у якому репрезентовано кореляції між ідентичністю юнака Джона й рольовою груповою ідентичністю, яка іманентно чужа протагоністові. Джон не поділяє цінностей інших спільнот. У ситуації конфлікту в громадському транспорті він пристає на бік батька й розуміє, що для інших вони є об'єктом глузування. Водночас у ситуації, коли батько топить маленьких кошенят, Джон розуміє, що навіть у найдорожчих людях закладено потяг до жорстокості, яка може виявлятися як елемент побутової реальності, що містить форми карнавального дійства. Комунікація Джона 3 іншими нагадує постійне потрапляння в карнавальний простір, у якому персонажі прагнуть приховати власні погляди й, відповідно, власну ідентичність, яка тепер має бути заміщена таким типом ідентичності, що не протистоїть ідентичності 
групи, до якої вони належать. Спільнота школярів, сусіди, батьки - зображені в романі М.Дж. Гайленд соціальні групи будують власну стратегію життя на принципі тотальної неправди, яка, як у випадку 3 бабусею, уже стає органічною частиною їх світосприйняття й життєсвіту, проте на якомусь глибинному фізіологічному рівні не може бути сприйнята протагоністом роману. Джон, як і Кристофер, пишу щоденник, що засвідчує тенденцію до наближення "Угамуйте мене" до категорії "его-роману", для якого важливим чинником є зображення реального контенту. Щоденник постає однією 3 форм експлікації "літератури факту", тобто такої літератури, що містить форми індивідуальної пам'яті, досвіду, позначаючи позицію головного персонажа й словесно візуалізуючи його індивідуальну історію формування його ідентичності.

Фактологічна домінанта постпостмодерністських романів дає можливість реципієнтам експлікуючи ідентичнісну специфіку персонажів, зокрема в аспекті психологічних особливостей. "Его-наратив" уможливлює занурення в художній простір, даючи можливість розкрити сконструйованих письменниками персонажів в антропологічному аспекті. Короткі речення, часто прості, без форм синтаксичних ускладнень, а також зорові малюнки, візуальні схеми та ін. дають можливість наблизитися у феноменологічному розумінні до сприйняття Іншого. Проблематика, пов'язана 3 пізнанням Іншого (носієм аутичного мислення, розуміння біологічних основ поведінкових реакцій персонажів тощо) належить до ключових у річищі сучасного британського роману, який дедалі інтенсивніше інкорпорує в себе реальне. Подібна тенденція знаходить своє втілення в англійській літературі давніших культурноісторичних періодів, зокрема в епоху пізнього Ренесансу [17]. Д. Г'юм, чиї філософські праці мали значний вплив на розвиток просвітницьких тенденцій у дискурсі англійської літератури, "розглядає проблему ідентичності як таку, що потребує самостійного вивчення. Ідентичність він розуміє як "тотожність особистості", водночас ставлячи ऑї під сумнів. Автор розглядає ідентичність як таку, що не володіє незмінністю та раціональністю. Він звертається до враження та сприйняття, які змушують ідентичність змінюватися" [17]. Англійська література XX ст. була особливо уважною до зображення персонажів в аспекті тілесних репрезентацій: дискурс тілесності водночас увиразнює й дискурс розуму, оскільки, відповідно до праць Ф. Штейнбука, тіло в концепції тілесного міметизму нерозривно пов'язане 3 мисленням і свідомістю. Новітні дослідження в царині психології залучаються англійськими письменниками для створення персонажів, наділених особливим типом світосприйняття, що з точки зору суспільства позиціоноване як "Інше". Водночас такі романи дають можливість змістити акценти в сприйнятті персонажів із особливим потребами, які з категорії "Чужого" (небезпечний соціопат) переходять у площину "Іншого", який є частиною зазначеної спільноти й, по суті, може бути корисним для її функціонування.

Ключовою в дискурсі постпостмодернізму постає "автентика ідентичності", тобто конструювання персонажами автентичної ідентичності, що відображає їх іманентну сутність. Л. Чорна, досліджуючи феномен конструювання цілісної ідентичності індивіда, зауважує: "Психологічний аспект формування рольової ідентичності особистості полягає не тільки в "суб'єктивному забарвленні" виконуваної нею певної ролі, а й у впливі особливостей реальної малої групи на репертуар ролей, які може обрати в "груповому рольовому полі" особистість, нормативних вимог групи до їх програвання тощо. Одним із найактуальніших питань дослідження рольової ідентичності $є$ також з'ясування шляхів інтеграції різних ролей особистості, які вона виконує, та їх зведення в єдину ідентичність" [1: 123]. У дискурсі постпостмодерністського роману експліковано мотив розщеплення ідентичності або ж представлення персонажа як носія різних ідентичностей, склеювання яких часто має проблематизований вияв. Водночас саме конфліктність деяких рольових ідентичностей усередині загальної ідентичності персонажа визначає конфлікт художнього твору, експлікуючи пошук автентичної ідентичності, яка й визначає справжнє, а не фіктивне, тобто удаване світосприйняття персонажами реальності. "Рольова ідентичність визначатиме зв'язок (або один із видів зв'язку) між індивідуальною та соціальною ідентичністю як форму подолання суперечностей між ними. Якщо мала група у своєму розвитку набуває характеристик суб'єктності, то між індивідуальною і соціальною ідентичністю не виникає конфлікту. Члени такої малої групи разом визначають цілі діяльності та досягають їх, виявляють спільну активність, усвідомлюють єдність думок, дій, а разом із тим поважають індивідуальні погляди іншого, цінують його своєрідність. Групова ідентичність, лояльність до групи їі членів підпорядковується індивідуальній ідентичності та відчуттю "суб'єктності групи". За таких обставин людина стає сама суб'єктом ролей: обирає в "рольовому полі" малої групи ті ролі, які сприяють розв'язанню завдань, що постають перед групою, гнучко змінює ролі, якщо того вимагає ситуація" [1: 126]. Кристофер із "Дивного випадку..." й Джон із "Угамуйте мене" розуміють свою інакшість і, відповідно, прагнуть сприйняти причини власної конфліктності із зовнішнім світом. Для обох персонажів причина такої проблемної взаємодії криється в неприйнятті неправди як чинника формування рольової індивідуальної ідентичності. Зазначена тенденція візуалізує те, що В. Франкл називає "фрустрацією устремління до смислу" [18: 64]. Дослідник зазначає, що "сьогодні люди позбавлені напруги. Насамперед вони зобов’язані цим тій утраті смислу, яку я описую як екзистенційний вакуум або фрустрацію устремління до смислу" [18: 64]. Ця утрата, можна припустити, детермінована 
сформованими соціальними груповими ідентичностями, які уможливлюють існування неправди як чинника уникнення потреби у смислах, які визначають напругу, про яку пише В. Франкл. Існування напруги (трагічних зіткнень індивіда з соціумом тощо) дає можливість сприйняти нові смисли, що мають смислобуттєвий характер.

"Патологія ідентичності" постає знаковою антропологічною художньою моделлю, представленою в значній кількості сучасних британських романів. Патологія може бути пов'язана 3 пережитою раніше травмою або потужним психоемоційним потрясінням, або ж детермінована особливістю генетичних розладів і невралгічних захворювань (персонажі романів "Дивний випадок із собакою вночі" М. Геддона, персонажі роману "Субота" I. Мак’юена тощо). Водночас сучасній британські автори розкривають досі не знані грані таких "патологічних ідентичностей", зокрема ж у тому підтипі, що виникає в результаті генетичної специфіки персонажів, як брак дзеркальних нейронів, що спричиняє аутизм (синдром Аспергера, синдром саванта та ін.). Патологічність у класичному розумінні цього поняття представлена в романі "Маленький незнайомець", де протагоніст доктор Фарадей не може подолати й "пропрацювати" потужної травми, яку переживає в дитячому віці. Пам'ять про цю подію з минулого стає пусковим механізмом, що ініціює створення фіктивної патологічної ідентичності, що живе лише бажанням помсти до своїх кривдників. Натомість у романі "Угамуйте мене" Джон конструює фіктивну ідентичність, яка витісняє спогади про трагічне зіткнення з батьками: ідентичність у романі вписана в наративну стратегію твору й постає ії органічним чинником.

Висновки та перспективи подальшого дослідження проблеми. Отже, в британських постпостмодерністських романах [19-22] увиразнено психологічні аспекти, пов'язані з конструюванням персонажів та репрезентацією їх ідентичностей. Мотив самопізнання в аспекті самоусвідомлення ідентичності $\epsilon$ важливим чинником у романах "Дивний випадок із собакою вночі" М. Геддона та "Угамуйте мене" М. Дж. Гайленд. Фактологічна домінантна сучасних британських романів дає підстави зарахувати їх до дискурсу "літератури факту" або ж "его-літератури". Проблема адаптації індивідуальної рольової ідентичності до рольової групової ідентичності, сформованої в певній спільноті, $\epsilon$ одним із ключовим проблемно-тематичних вузлів сучасного британського роману.

\section{СПИСОК ВИКОРИСТАНИХ ДЖЕРЕЛ ТА ЛІТЕРАТУРИ}

1. Чорна Л. Рольова ідентичність : їі локалізація серед інших видів ідентичності особистості / Л. Г. Чорна // Наукові студії із соціальної та політичної психології. - 2011. - Вип. 27. - С. 120-129. - Режим доступу : http://nbuv.gov.ua/UJRN/Nsspp_2011_27_16.

2. Антонова Н. В. Проблема личностной идентичности в интерпретации современного психоанализа, интеракционизма и когнитивной психологии / Н. В. Антонова // Вопросы психологии. - 1996. - № 1. C. $131-142$.

3. Горностай П. П. Личность и роль: Ролевой подход в социальной психологии личности / П. П. Горностай. К. : Интерпресс ЛТД, 2007. - 312 с.

4. Зливков В. Л. Проблема особистісної та професійної самоідентифікації в сучасній психології / В. Л. Зливков // Соціальна психологія. - 2006. - № 5. - С. 128-136.

5. Gordon Ch. Development of evaluated role identities / Ch. Gordon // Annual Review of Sociology. - 1976. - V. 2. - P. 405-433.

6. Lamarque P. Truth, Fiction and Literature. A Philosophical Perspective / P. Lamarque, S. Olsen. - Oxford: Clarendon Press, 1994. - 481 p.

7. Штейнбук Ф. Конвергенція топосу ідентичності у сучасній світовій літературі / Ф. Штейнбук // Науковий часопис Національного педагогічного університету імені М.П. Драгоманова. Серія 8: Філологічні науки (мовознавство і літературознавство) : зб. наук. статей. - Київ : Вид-во НПУ імені М. П. Драгоманова, 2017. - Вип. 8. - С. 106-112.

8. Эриксон Э. Детство и общество / Э. Эриксон. - [2-е изд.]. - СПб. : Ленато, 2006. - 592 с.

9. Эриксон Э. Идентичность : юность и кризисы / Э. Эриксон. - М., 1996. -344 с.

10. Эриксон Э. Трагедия личности / Э. Эриксон. - М. : Алгоритм, Эксмо, 2008. - 256 с.

11. Колошук Н. Нефікційна література (документалістика) як маргінальне явище мультикультурного процесу сучасності : українська ситуація / Н. Колошук // Питання літературознавства. - Чернівці : ЧНУ, 2009. Вип. 78. - С. 215-223.

12. Михеев М. Ю. Дневник как эго-текст (Россия, XIX - XX) / М. Ю. Михеев. - М. : Водолей Publishers, 2007. $264 \mathrm{c}$.

13. Осадча Ю. В. Его-белетристика як жанр: питання поетики (на матеріалі японської та української прози) : автореф. дис. на здобуття наук. ступеня канд. філол. наук : спец. 10.01.06 "Теорія літератури" / Ю. В. Осадча. - К., 2006. - 20 с.

14. Дуркалевич В. В. У пошуках наративної ідентичності: індивідуальний міф у творах Івана Франка, Анджея Хцюка і Бруно Шульца / Вікторія Володимирівна Дуркалевич. - Дрогобич : Коло, 2015. - 366 с.

15. Шалагінов Б. Б. Карнавал і містерія : роздуми про історичні долі двох метаформ європейського мистецтва / Борис Борисович Шалагінов // Всесвіт. - 2011. - №3-4. - С. 249-255.

16. Loftis S. F. Imagining Autism: Fiction and Stereotypes on the Spectrum / Sonya Freeman Loftis. - Indiana University Press, 2015. - 208 p. 
17. Правдивець Н. О. Теоретична модель феномену ідентичності особистості [Електронний ресурс]/ Н. О. Правдивець. - Режим доступу : http://ifreestore.net/937.

18. Франкл В. Человек в поисках смысла : сборник: пер. с англ. и нем. / Общ. ред. Л. Я. Гозмана и Д. А. Леонтьева. - М. : Прогресс, 190. - 368 с.

19. Гайленд М. Дж. Угамуйте мене ; [пер. з англ. Віктор Дмитрук] / М. Дж. Гайленд. - Львів : Кальварія, 2008. $-248 \mathrm{c}$.

20. Haddon M. The Curious Incident of the Dog in the Night-Time / Mark Haddon. - London : Vintage, 2004. -226 p.

21. Mitchell D. Cloud Atlas: a novel / David Mitchell. - London : Random House, 2004. - 509 p.

22. Waters S. The Little Stranger / S. Waters. - London-NY: Riverhead Trade, 2009. -528 p.

\section{REFERENCES (TRASLATED \& TRANSLITERATED)}

1. Chorna L. Rolova identychniste : yii lokalizatsiia sered inshykh vydiv identychnosti osobystosti [Role's Identity: Its Localization among Other Types of Personality Identity] / L. H. Chorna // Naukovi studii iz sotsialnoi ta politychnoi psykholohii [Scientific Studies in Social and Political Psychology]. - 2011. - Vyp. 27. - S. 120-129. Rezhym dostupu : http://nbuv.gov.ua/UJRN/Nsspp_2011_27_16.

2. Antonova N. V. Problema lichnostnoi identichnosti v interpretatsii sovremennogo psikhoanaliza. interaktsionizma i kognitivnoi psikhologii [The Problem of Personal Identity in the Interpretation of Modern Psychoanalysis, Interaction and Cognitive Psychology] / N. V. Antonova // Voprosy psikhologii [Issues of Psychology]. - 1996. № 1. - S. 131-142.

3. Gornostay P. P. Lichnost' i rol' : Rolevoi podkhod v sotsialnoi psikhologii lichnosti [Personality and Role: Role Approach in the Social Psychology of Personality] / P. P. Gornostay. - K. : Interpress LTD. 2007. - 312 s.

4. Zlyvkov V. L. Problema osobystisnoi ta profesiinoi samoidentyfikatsii v suchasnii psykholohii [The Problem of Personal and Professional Self-Identification in Modern Psychology] / V. L. Zlyvkov // Sotsial'na psykholohiia [Social Psychology]. - 2006. - № 5. - S. 128-136.

5. Gordon Ch. Development of Evaluated Role Identities / Ch. Gordon // Annual Review of Sociology. - 1976. V. 2. - P. 405-433.

6. Lamarque P. Truth, Fiction and Literature. A Philosophical Perspective / P. Lamarque, S. Olsen. - Oxford : Clarendon Press, 1994. - 481 p.

7. Shteinbuk F. Konverhentsiia toposu identychnosti u suchasnii svitovii literaturi [Convergence of the Identity Topos in Contemporary World Literature] / F. Shteinbuk // Naukovyi chasopys Natsional'noho pedahohichnoho universytetu imeni M. P. Drahomanova. Seriia 8 : Filolohichni nauky (movoznavstvo i literaturoznavstvo) [Scientific Bulletin of M. Drahomanov Pedagogical University. Philological Issues (Linguistics and Literary Studies)]. - Kyiv : Vyd-vo NPU imeni M. P. Drahomanova, 2017. - Vyp. 8. - S. 106-112.

8. Erikson E. Detstvo i obshchestvo [Childhood and Society] / E. Erikson. - SPb. : Lenato. 2006. - $592 \mathrm{~s}$.

9. Erikson E. Identichnost' : yunost' i krizisy [Identity : Youth and Crises] / E. Erikson. - M., 1996. - 344 s.

10. Erikson E. Tragediia lichnosti [Tragedy of Personality] / E. Erikson. - M. : Algoritm. Eksmo. 2008. - $256 \mathrm{~s}$.

11. Koloshuk N. Nefiktsiina literatura (dokumentalistyka) yak marhinal'ne yavyshche mul'tykul'turnoho protsesu suchasnosti : ukrains'ka sytuatsiia [Non-Fiction Literature (Documentary) as a Marginal Phenomenon of the Multicultural Process of the Present : Ukrainian Situation] / N. Koloshuk // Pytannia literaturoznavstva [Problems of Literary Criticism]. - Chernivtsi : ChNU, 2009. - Vyp. 78. - S. 215-223.

12. Mikheyev M. Yu. Dnevnik kak ego-tekst (Rossiia. XIX - XX) [Diary as an Ego-Text (Russia, XIX - XX)] / M. Yu. Mikheyev. - M. : Vodoley Publishers. 2007. - 264 s.

13. Osadcha Yu. V. Ego-beletrystyka yak zhanr : pytannia poetyky (na materiali yaponskoi ta ukrains'koi prozy) [EgoFiction as a Genre : the Questions of Poetics (on the Material Japanese and Ukrainian Prose)] : avtoref. dys. na zdobuttia nauk. stupenia kand. filol. nauk: spets. 10.01.06 "Teoriia literatury" / Yu. V. Osadcha. - K., 2006. - 20 s.

14. Durkalevych V. V. U poshukakh naratyvnoi identychnosti : indyvidual'nyi mif u tvorakh Ivana Franka, Andzheia Khtsiuka i Bruno Shultsa [In Search of a Narrative Identity: an Individual Myth in the Works of Ivan Franko, Andrzej Hcyuk and Bruno Schultz] / V. V. Durkalevych. - Drohobych : Kolo, 2015. - $366 \mathrm{~s}$.

15. Shalahinov B. Karnaval i misteriia : rozdumy pro istorychni doli dvokh metaform yevropeiskoho mystetstva [Carnival and Mystery: Reflections on the Historical Destinies of Two Metaforms of European Art] / Borys Shalahinov // Vsesvit [Universe]. - 2011. - № 3-4. - S. 249-255.

16. Loftis S. F. Imagining Autism : Fiction and Stereotypes on the Spectrum / S. F. Loftis. - Indiana University Press, 2015. $-208 \mathrm{p}$.

17. Pravdivets N. O. Teoretichna model' fenomenu identichnosti osobistosti [Theoretical Model of the Phenomenon of Identity of the Individual] [Elektronnyi resurs] / N. O. Pravdivets. - Rezhym dostupu : http://ifreestore.net/937.

18. Frankl V. Chelovek v poiskakh smysla [Man in Search of Meaning] / F. Frankl. - M. : Progress. 190. $-368 \mathrm{~s}$.

19. Hailend M. Dzh. Uhamuite mene ; [Carry Me Down] / M. Dzh. Hailend. - Lviv : Kalvariia, 2008. - $248 \mathrm{~s}$.

20. Haddon M. The Curious Incident of the Dog in the Night-Time / M. Haddon. - London : Vintage, 2004. - 226 p.

21. Mitchell D. Cloud Atlas : a Novel / D. Mitchell. - London : Random House, 2004. - 509 p.

22. Waters S. The Little Stranger / S. Waters. - London-NY : Riverhead Trade, 2009. -528 p.

\section{Дроздовский Д. И. Психологическая идентичность персонажей британских постпостмодернистских романов: дискурс эго-литературы.}

В статье исследован психологизм британских постпостмодернистских романов. На материале современных романов С. Уотерс, И. Макьюэна, М.Дж. Хайленд, М. Хэддона, Д. Митчелла 
обосновывается концепџия постмодернистских идентичностей, представленная в работах Ф. Штейнбука. Отмечается перспективность представленной теории в литературном дискурсе постпостмодернизма. Представлены модели репрезентации ролевой идентичности как компонента постпостмодернистской художественной идентичности и проанализированы конфликты между индивидуальной идентичностью и идентичностью группы. Акиентируется, что интенсивное выявления психологизма в современных романах детерминировано развитием эго-литературы, которая предусматривает конструирование опытов субъекта наррации, который путем написания дневника осуществляет самопознание и одновременно объясняет себя другим. Охарактеризованы возможности расширения теоретико-методологического поля современных литературоведческих исследований путем привлечения психологических подходов и результатов исследований личностной идентичности в аспекте теории игр, трансактного анализа и проч.

Ключевые слова: постпостмодернизм, британский роман, эго-роман, ролевые идентичности, аутизм, постпостмодернистские идентичности, литература факта.

\section{Drozdovskyi D. I. Psychological Identity of Characters of British Post-Postmodern Novels: Discourse of Ego- Literature.}

In the paper, I investigate the psychology of British post-postmodern novels. On the material of contemporary British novels written by S. Waters, I. McEwan, M.J. Hyland, M. Haddon, D. Mitchell the concept of postmodern identities presented in the researches of F. Shteinbuk has been developed and outlined. It is emphasized on the perspective of the presented theory in the literary discourse of post-postmodernism. The models of representation of "role identity" as a component of post-postmodern literary identity have been outlined and conflicts between individual identities and group identity have been analyzed. Intensified detection of psychology in contemporary novels is determined by the development of ego-literature, which involves constructing the experiences of the subject of narration, which, by writing a diary, carries out self-knowledge and, at the same time, explains it to others. The possibilities of expanding the theoretical and methodological field of contemporary literary theory by means of psychological approaches and results of psychological studies on personal identity in the aspect of role theory, transactional analysis, etc. have been discussed in the research. It was spotlighted that the problem of adapting individual role identity to the role group identity formed in a particular community is one of the key problem-thematic knots in contemporary British novels. The factual dominant of post-postmodern novels enables the way to expose the identity of the characters, in particular in the aspect of psychological peculiarities. Ego-narrative gives an opportunity to reveal the characters constructed by writers in the anthropological aspect. Short sentences, simple, without forms of syntactic complications, as well as visual drawings, visual diagrams, etc. give an opportunity to get closer in the phenomenological sense to the perception of the Other in the contemporary novelistic discourse. It is proved that the problems associated with understanding of the Other (the bearer of autistic thinking, understanding of the biological basis of behavioral reactions of characters, etc.) belongs to the key in contemporary British novel, which incorporates the real content.

Key words: post-postmodernism, British novel, ego-novel, role identity, autism, post-postmodern identities, literature of fact. 